\title{
E-MODUL PEMBELAJARAN BAHASA INGGRIS UNTUK SISWA SMP N 1 TAKENGON
}

\author{
E-MODULE LEARNING ENGLISH \\ FOR STUDENTS SMP N 1 TAKENGON
}

\author{
Ichwan Mahara $^{1}$, I Nyoman Sudana Degeng ${ }^{2}$, Dedi Kuswandi ${ }^{3}$ \\ Program Studi Teknologi Pembelajaran, \\ Pascasarjana Universitas Negeri Malang \\ Email: ichwan.mahara@yahoo.com
}

\begin{abstract}
ABSTRAK: Pengembangan ini bertujuan untuk: 1) menghasilkan produk berupa e-modul pembelajaran reading yang diharapkan dapat membantu siswa dalam mempelajari Bahasa Inggris khususnya pada teks descriptive dan procedure SMP kelas VII. 2) dapat meningkatkan hasil belajar siswa. Jenis penelitian adalah pengembangan $(R \& D)$ dengan model desain pembelajaran ASSURE. Subjek penelitian adalah siswa kelasVII SMP Negeri 1 Takengon semester genap tahun ajaran 2014/2015. Hasil penelitian menunjukkan bahwa secara keseluruhan produk media e-modul pembelajaran ini termasuk dalam kategori sangat layak digunakan dalam proses pembelajaran dan dapat meningkatkan hasil belajar siswa.
\end{abstract}

Kata Kunci : E-Modul, Bahasa Inggris

ABSTRACT: This development aims to 1) produce an e-module as a product for reading which can help the students in learning English subject, especially in descriptive text and procedure text in SPM class VII, 2) improve the students achievement. This study is Research and Development (R\&D) which ASSURE learning design model. The subjects are the students in class VII SMP N 1 Takengon 2014/2015. The result shows that this learning e-module is in very suitable category to be employed in learning process and can improve the students achievement in reading.

Keyword: E-Module, English Langguage

Pemanfaatan teknologi dalam dunia pendidikan merupakan upaya mempercepat pencapaian. Teknologi dianggap sebagai alat atau media yang dapat membantu dalam menyampaikan pesan yang dibuat sebagai materi kemudian disampaikan kepada yang menerima pesan tersebut dengan mudah. sehingga orang yang diberi pesan dengan mudahnya mengerti tentang apa yang dimaksud dalam pesan tersebut. (Muslim) juga menyatakan teknologi digunakan untuk mengolah data, termasuk memperoses, mendapatkan, menyusun, menyimpan, memanipulasi data dalam berbagai cara untuk menghasilkan informasi yang berkualitas, yaitu informasi yang relevan, akurat dan tepat waktu, yang digunakan untuk keperluan pribadi dan lain sebagainya. Dengan demikian dapat disimpulkan bahwa peran daripada teknologi adalah sebagai alat guna mempermudah tujuan dari pengguna itu sendiri.
Dengan memanfaatkan teknologi dalam dunia pendidikan, banyak hasil yang diperoleh dari perkembangan teknologi itu sendiri khususnya dalam dunia pendidikan, dimana banyak media-media pembelajaran berkembang seiring dengan perkembangan teknologi. (Arsyad 2011) menyatakan media adalah bagaian yang tidak dapat terpisahkan dari proses belajar mengajar demi tercapainya tujuan pendidikan pada umumnya dan tujuan pembelajaran pada khusunya. Lebih-lebih media pembelajaran merupakan starategi penyampaian (delivery strategy) mengacu pada cara-cara yang dipakai untuk menyampaikan pengajaran kepada sibelajar dan sekaligus untuk menerima serta merespon masukan-masukan dari sipebelajar (Degeng, 1989: 141).

Media memiliki pengertian fisik yang dewasa ini dikenal sebagai hardware (perangkat keras) yaitu suatu benda yang dapat dilihat, didengar, atau diraba dengan panca indra. Serta media juga memiliki 
pengertian nonfisik yang dikenal sebagai software (perangkat lunak), yaitu kandungan pesan yang terdapat dalam perangkat keras merupakan isi yang ingin disampaikan kepada siswa (Arsyad, 2011:6). Banyak jenis dan ciri-ciri media yang dapat digunakan dalam proses pembelajaran, salah satunya yang dikemukan (Suherman 2009) adalah modul.

Modul merupakan bahan ajar terprogram dan sistematis yang mana dibuat guna tercapainya tujuan pembelajaran dengan mudah tanpa memerlukan waktu yang cukup lama untuk memahaminya. Dick \& Carey dalam (Wena 2009:231) memberi pengertian bahwa "modul merupakan bahan pembelajaran cetak, fungsinya sebagai media belajar mandiri dan isinya berupa satu unit materi pembelajaran". Seiring dengan kemajuan teknologi, modul dapat disajikan dalam bentuk elektronik. Modul elektronik atau sering disebut e-modul merupakan tampilan informasi dalam format buku yang disajikan dalam bentuk elektronik dengan menggunakan harddisk, disket, $\mathrm{CD}$, atau flash disk dan dapat dibaca dengan menggunakan komputer atau alat pembaca elektronik (Mulyasa, 2005:43).

Penggunaan e-modul dapat mengontrol kemampuan dan intensitas belajar siswa, e-modul juga dapat membantu siswa mudah memahami materi praktek meskipun minimnya peralatan praktek dengan menampilkan gambar dan tutorial yang lengkap. E-modul dapat dipelajari di mana saja, siswa dapat belajar mandiri baik di rumah maupun diluar jam sekolah. Penggunaan e-modul tidak terbatas oleh waktu, walaupun dalam kemasan e-modul juga disebutkan waktu yang dibutuhkan untuk mempelajari materi tertentu, Akan tetapi keleluasaan siswa mengelola waktu tersebut sangat fleksibel.

Dalam kurikulum khusunya mata pelajaran Bahasa Inggris, merupakan mata pelajaran yang wajib dipelajri siswa. Siswa dituntut bukan hanya memahami materi tentang struktur bahasa ataupun tata bahasa saja, akan tetapi juga ditekankan pada kompetensi berbahasa sebagai alat komunikasi untuk menyampaikan gagasan dan pengetahuan (Kementerian Pendidikan dan Kebudayaan 2013:39).

Dalam mempelajari Bahasa Inggris, tentunya siswa dihadapi kendala-kendala dalam proses pembelajaranya. Salah satunya dengan terbatasnya jam belajar dan kurangnya media pembelajaran yang mendukung dan sesuai dengan kebutuhan siswa, sehingga berdampak pada hasil belajar siswa. Hal ini dapat dilihat saat peneliti melakukan observasi di lapangan yaitu SMP N 1 Takengon.

Berdasarkan permasalahan di atas, maka peneliti melakukan sebuah pengembangan berupa media pembelajaran yang berbentuk e-modul pembelajaran. Emodul ini dirancang guna membantu siswa dalam menguasai materi pembelajaran baik secara teori maupun praktek. Selain itu juga membantu guru dalam memberikan ataupun menyampaikan materi dengan mudah dengan e-modul tersebut, sehingga tercapainya tujuan pembelajaran sebagaimana yang diharapkan. Dan siswa tidak memiliki batas waktu untuk belajar dimana dan kapan saja.

Pengembangan ini didasari penelitian terdahulu yang mana dilakukan oleh (Masjkur \& Widjianto 2004) dalam pengembangan tersebut yaitu mengenai pengembangan modul dalam pembelajaran fisika bahwa dapat disimpulkan meningkatkan motivasi belajar dengan persentase meningkat $60 \%$. Namun dalam pengembangan itu mereka menyebutkan terdapat kekurangan yaitu diperlukanya media berupa komputer untuk menunjang pembelajaran. Kemudian juga dilakukan oleh (Agustina 2013) dalam penelitianya yaitu pengembangan modul pembelajaran berbasis elektronik pada mata pelajaran Biologi materi sistem imun untuk SMA kelas XI semester genap dimana dapat disimpulkan e-modul tersebut dapat dikategorikan layak dijadikan alternatif sumber belajar, hanya saja dalam catatan kesimpulanya beliau menyatakan sebaiknya guru memperhatikan persiapan yang dibutuhkan untuk keterlaksanaan pembelajaran. (Liufeto 2013) juga melakukan pengembangan e-modul fotografi dan hasil 
dari pengembangan tersebut dapat diambil kesilpulan kategori baik, sehingga dapat digunakan untuk bahan ajar fotografer. Terakhir (Wijayanto \& Zuhri 2004) dalam penelitianya melakukan pengembangan emodul berbasis flip book maker dengan model project base learning untuk kemampuuan pemecahan masalah matematika, dimana hasil dari pengembangan tersebut menunjukkan e-modul tersebut layak digunakan dan dapat membantu tercapainya tujuan pembelajaran.

Oleh sebab itu peneliti melakukan pengembangan lebih lanjut mengenai pengembangan e-modul khusunya pada mata pelajaran Bahasa Inggris guna membantu siswa dalam proses pembelajaran serta meningkatkan hasil belajar. Lebih-lebih siswa rata-rata memiliki teknologi pendukung berupa laptop, hand phone dan alat-alat lainya yang bisa dipakai untuk mendukung pengembangan ini pada saat penggunaanya pada saat proses pembelajaran berlangsung.

\section{METODE}

Metode penelitian dan pengembangan yang digunakan dalam penelitian ini adalah metode R\&D (Research and Development) dengan model desain Pembelajaran ASSURE (Analyze learner characteristics, State Objective, Select methods, media and material, Utilize, Require learner partisipation, Evaluate and Revise). Model ASSURE ini merupakan model pembelajaran yang lebih menekankan pada kesesuaian antara materi dengan pemilihan media dan metode yang diterapkan dalam setiap proses pembelajaran. Dalam pelaksanaannya model ASSURE mempunyai 6 langkah tindakan yang meliputi (1) analisis pebelajar; (2) menentukan tujuan pembelajaran; memilih metode, media dan materi; menggunakan media dan materi; mendorong partisipasi pebelajar: dan Evaluasi dan perbaikan.

Alasan pemilihan model pengembangan model ASSURE adalah 1) Sistematis, 2) Sederhana, relatif mudah untuk diterapkan, 2) Dapat dikembangkan sendiri oleh pengajar, 3) Komponen KBM lengkap.

Selain itu dari data hasil penelitian sebelumnya model ASSURE mampu meningkatkan hasil belajar, motivasi dan menyediakan pengalaman belajar bagi pebelajar.

\section{HASIL}

Hasil produk dari pengembangan ini berupa e-modul pembelajaran Bahasa Inggris dengan standar kompetensi membaca fokos pada materi teks prosedure dan descriptive. Modul dikemas dalam CD dan dapat diinstal pada HP berbasis android serta dilengkapi dengan buku petunjuk penggunaan sebagai pemandu bagi pengguna. Selanjutnya setelah produk ini jadi, kemudian dilakukan validasi ahli, baik ahli materi, ahli desain dan ahli materi guna menilai dan menaggapi produk tersebut. Selanjutnya penilaian dan tanggapan dijadikan sebagai masukan guna merevisi produk, sekaligus sebagai evaluasi terhadap produk yang dikembangkan.

\section{PEMBAHASAN}

\section{Prosedur}

pengembangan

menggunakan

ini, model

engembangan. Pada pelaksanaanya memiliki enam langkah tindakan yang meliputi (1) analisis pebelajar; pada langkah ini pengembang mengamati karakteristik umum siswa, dimana hasil pengamatan tersebut siswa terdiri dari berbagai etnis yang berbeda dan kebanyakan dari mereka telah mampu menggunakan laptop/gadget sebagai sarana belajar. Kemudian jika dilihat dari gaya belajar siswa, siswa memiliki pariasi dalam hal gaya belajar, ada yang aktif namum masih ada juga yang enggan untuk mengeluarkan pendapat. Namum dilihat dari segi kemampuan awal siswa dalam belajar Bahasa Inggris, siswa (3) rata-rata dapat mengikuti dan memahaminya, (4) sebab mereka sebelumnya telah (5) mempelajarinya pada semester ganjil sebagai (6) dasar belajar selanjutnya. (2) menentukan tujuan pembelajaran; pada langkah ini pengembang mengacu pada silabus dan RPP yang telah ada, sebab pengembang bertujuan untuk menghasilkan produk yang dapat digunakan oleh siswa dalam proses pembelajaran dan dapat meningkatkan hasil 
belajar siswa, sehingga produk yang dikembangkan sesuai dengan materi yang ada dilapangan. (3) memilih materi, metode dan media; materi yang digunakan dalam pengembangan ini adalah teks descriptive dan procedure, sesuai dengan yang dijabarkan dalam silabus dan RPP pembelajaran Bahasa Inggris SMP kelas VII. Sedangkan metode dalam pembelajaranya adalah metode CIRC yaitu metode yang dianggap sesuai dengan pembelajaran teks. Yang terakhir media yang dikembangkan dalam pengembangan ini adalah elektronik modul yang sering disebut e-modul dimana selain didalamnya terdpat materi juga memiliki audio dan gambar untuk memberikan daya tarik tersendiri bagi pengguna dan dapat juga diinstal pada hand phone berbasis android yang berguna sebagai pembelajaran individual. (4) menggunakan materi,metode dan media; pada langkah ini, penggunaanya secara bersamaan pada saat proses pembelajaran ketiganya masingmasing saling memberikan kontribusi sesuai dengan fungsinya masing-masing. Materi sebagai isi atupun materi yang diajarkan sedangkan metode merupakan strategi penyampaian isi tersebut dan media sebagai alat upaya mempermudah penyampaian lebih efisien. (5) mendorong partisipasi pebelajar; dalam penerapan e-modul ini, siswa lebih mendapatkan kesenangan dalam belajar, sebab e-modul dirancang memiliki audio bagaimana cara membaca yang benar dan sesuai dengan teks yang terdapat dalam media. Serta media ini memiliki gambar sebagai objek kajian pada materi sehingga pemahaman siswa tentang apa yang dijelaskan dapat tercapai. (6) evaluasi dan perbaikan; setiap masukan dari para ahli dan uji coba digunakan sebagai masukan untuk menyempurnakan produk yang dikembangkan, sehingga setiap tahapan validasi setelah mendapatkan saran makan dilakukan revisi sebagai perbaikan terhadap produk sehingga produk siap digunakan. Inilah langkah-langkah yang terdapat dalam pengembangan ini sebagai acuan kerangka dasar dalam pengembangan produk e-modul ini.
Kegiatan yang dilakukan.

Pengembangan ini sebelum digunakan dalam pembelajaran, terlebih dahulu dilakukan validasi untuk menilai dan mendapatkan tanggapan-tanggapan terhadap produk yang dikembangkan. Validasi ini terdiri dari validasi ahli materi, ahli desain dan ahli media. Kemudian tahap selanjutnya adalah uji coba, baik uji coba perorangan, kelompok kecil dan terakhir kelompok besar atau audiens. Hal ini dilakukan secara bertahap demi kesempurnaan produk yang dikembangkan dan hasil dari validasi ini sebagai penilaian terhadap produk.

Analisis kekuatan \& kelemahan. Kekuatan ataupun kelebihan dari produk ini adalah produk ini dilengkapi dengan ilustrasi gambar, audio dan teks yang dapat membantu siswa memahami materi pembelajaran serta dilengkapi dengan buku petunjuk penggunaan siswa dan guru sehingga dapat membantu siswa dan guru dalam memudahkan penggunaan dan terakhir dapat dijadikan sebagai sumber belajar selain buku paket dan LKS pembelajaran sehingga lebih modern dan muktahir. Selain memiliki kelebihan ternyata masih terdapat kelemahan diantaranya karna kemasan e-modul ini dikemas dalam CD maka untuk menggandakan membutuhkan biaya yang cukup mahal dan jika ingin memperbaharui materi e-modul ini membutuhkan waktu yang cukup lama dan harus bisa menguasai software pembuatanya.

\section{KESIMPULAN DAN SARAN}

Dari hasil analisis data yang diperoleh baik validasi Ahli, uji coba produk dan analisis data hasil belajar siswa, dapat disimpulkan bahwasanya produk yang dihasilkan berupa e-modul pembelajaran Bahasa Inggris khususnya pada teks descriptive dan procedure SMP kelas VII ini dapat dikategorikan sangat layak digunakan pada saat proses pembelajaran dan juga dapat meningkatkan hasil belajar siswa.

Hal ini dibuktikan dengan hasil presentase uji coba ahli materi sebesar $73 \%$. Berdasarkan kriteria, media e-modul ini termasuk kualifikasi layak, hasil presentase uji coba ahli desain sebesar $91 \%$. 
Berdasarkan kriteria, e-modul ini termasuk kualifikasi sangat layak, hasil presentase uji coba ahli media sebesar 93,3\%. Berdasarkan kriteria, e-modul ini termasuk kualifikasi sangat layak sedangkan hasil presentase uji coba audiens/siswa perorangan sebesar $86,2 \%$. Berdasarkan kriteria, media e-modul ini termasuk kualifikasi sangat layak, hasil presentase uji coba audiens/siswa kelompok kecil sebesar 89,0\%. Berdasarkan kriteria, media e-modul ini termasuk kualifikasi sangat layak, hasil presentase uji coba audiens/siswa lapangan sebesar $86,6 \%$. Berdasarkan kriteria, media e-modul ini termasuk kualifikasi sangat layak.

Meskipun secara keseluruhan media pembelajaran yang dikembangkan sangat layak, namun ada beberapa aspek yang perlu direvisi. Untuk itu revisi perlu dilakukan berdasarkan saran-saran oleh ahli media, ahli desain, ahli materi dan tanggapan audiens/siswa.

Setelah dilakukan validasi ahli dan uji coba siswa kemudian dilanjutkan dengan tes akhir untuk mengetahui kelayakan penggunaan e-modul serta melihat apakah produk dapat meningkatkan hasil belajar siswa. Untuk tes hasil belajar, rata-rata hasil belajar 92,5 dari 28 siswa. Terdapat 24 siswa $(85,7 \%)$ yang mencapai SKM dan yang belum mencapai SKM 4siswa (14,2\%). Dengan demikian, dapat disimpulkan bahwa jumlah siswa yang memenuhi SKM mencapai tingkat prosentase $92,5 \%$ sehingga e-modul ini layak untuk digunakan dalam proses pembelajaran dan dapat meningkatkan hasil belajar siswa.

Saran pemanfaatan. Dalam upaya penyebaran dan pemanfaatan hasil pengembangan, maka diajukan beberapa saran sebagai berikut: (1) Para guru bahasa inggris diharapkan menggunakan produk media e-modul ini sebagai contoh variasi produk media pembelajaran, (2) Selain digunakan sebagai media pembelajaran klasikal, diharapkan juga dapat digunakan secara individual sebagai proses belajar mandiri bagi peserta didik, (3) Sosialisasi produk media pembelajaran ini juga diperlukan. Harapanya dapat membantu peran guru dalam proses pembelajaran dan dapat diaplikasikan pada semua jenjang pendidikan yang nantinya dapat dikembangkan lebih baik, lebih kreatif dan lebih inovatif.

Saran pengembangan lebih lanjut. E-modul ini hendaknya dikembangkan lebih baik sehingga dapat memberikan hasil yang lebih baik lagi. Mengkaji lebih dalam pada saat pemilihan materi dan pemilihan software yang digunakan. Akan lebih baik lagi jika pengembangan selanjutnya tidak hanya menyediakan satu mata pelajaran tetapi terdapat berbagai mata pelajaran yang dapat diikuti oleh siswa sehingga tidak hanya mata pelajaran Bahasa Inggris.

\section{DAFTAR RUJUKAN}

Agustina, 2013. Pengembangan Modul Pembelajaran Berbasis Elektronik Pada Mata Pelajaran Biologi Materi Sistem Imun Untuk Sma Kelas Xi Semester 2. Tesis tidak diterbitkat. Malang: PPs UM.

Arsyad, A. 2011. Media Pembelajaran. Jakarta: PT Raja Grafindo Persada.

Degeng, I.N.S. 1989. Ilmu Pengajaran: Taksonomi Variable. Jakarta:

Departemen Pendidikan dan Kebudayaan.

Kementerian Pendidikan dan Kebudayaan Tahun 2013 tentang Kerangka Dasar dan Struktur Kurikulum 2013. 2013. Jakarta: Kementerian Pendidikan dan kebudayaan RI.

Liufeto, M.C. 2013. Pengembangan E-modul fotografi. Tesis tidak diterbitkat. Malang: PPs UM.

Masjkur, K. \& widjianto. 2014. Pengembangan Modul Fisika Materi Statis dengan Model POE (Predict-Observe-Explain) Berbantuan digital untuk Meningkatkan Motivasi Belajar siswa SMA Kelas X KRISTA YOHANA, 2 (1). (Oline), ( http://jurnal-

online.um.ac.id/article/do/detailarticle/1/35/1435), diakses 25 November 2014.

Mulyasa, E. 2005. Implementasi kurikulum 2004 panduan pembelajaran KBK. Bandung : PT Remaja Rosda karya.

Suherman, Y. 2009. Pengembangan Media Pembelajaran Bagi ABK. Makalah disajikan pada diklat profesi Guru PLB wilayah X Jawa Barat bumi makmur, 
Bandung 2008. Dalam file UPI, (Online), (http://file.upi.edu/Direktori/FIP/JUR._P END._LUAR_BIASA/196610251993031

YUYUS_SUHERMAN/I._Makalah/Peng embangan media Pembelajaran.pdf), diakses 24 November 2014.

Wena, M. 2009. Strategi Pembelajaran Inovatif Kontemporer. Jakarta: Bumi Aksara.

Wijayanto \& Zuhri, S.M. 2014.

PENGEMBANGAN E-MODUL BERBASIS FLIP BOOK MAKER DENGAN MODEL PROJECT BASED LEARNING UNTUK MENGEMBANGKAN KEMAMPUAN PEMECAHAN MASALAH MATEMATIKA, (Online), (http://prosiding.upgrismg.ac.id/index.ph p/masif2014/masif2014/paper/viewFile/4 87/436), diakses 14 Juni 2015. 